\title{
Legal Protection for Consumers on Online Trade of Imported Food Products That Do Not Have a Circulation License in Indonesia
}

\author{
Maswandi ${ }^{1}$, Jamillah ${ }^{2}$, Widyawati Anggresia Manihuruk ${ }^{3}$ \\ ${ }^{1,2,3}$ Faculty of Law, Universitas Medan Area, Indonesia \\ maswandi@staff.uma.ac.id
}

\begin{abstract}
Legal protection for consumers for online trading of imported food products without a distribution permit is something that is very important to do in Indonesia, considering that for consumers to obtain any goods through buying and selling is not something difficult in the era of modern technology at this time with the presence of online media, but maintaining the health of certain food products is the main goal for everyone. The presence of online media makes it easier for consumers and business actors to access buying and selling transactions. The online media that are widely used by business actors include Instagram, Facebook, WhatsApp and so on. However, the existence of several products in the form of imported food without a distribution permit sold online from business actors will certainly have a negative impact on consumers as buyers, especially the impact on health caused by food products. Although Law no. 8 of 1999 concerning Consumer Protection can be used as an umbrella to provide protection for consumers. However, considering that the regulation does not stipulate a supervisory mechanism for business actors who do not have a distribution permit, so that the legal protection that is implemented cannot run properly as determined, that's why there are still many business actors in trading imported food products that do not yet have a license. distribution permit which ultimately does not provide legal protection for consumers properly is the cause of the weak regulation on consumer protection.
\end{abstract}

Keywords

legal protection; consumers; online trading; distribution permit

\section{Introduction}

It is undeniable that food is one of the basic needs of human life, so it can be said that without eating and drinking sufficient quantity and quality, humans will be hindered in carrying out their daily activities. Article 1 number 1 of Law Number 18 of 2012 concerning Food states that food is everything that comes from biological and water sources, both processed and unprocessed, which is intended as food or drink for humans, including food additives, raw materials, food, and other materials used in the process of preparing, processing, and/or making food and beverages. Food issues are also related to security, safety and health.

The development of an increasingly modern era has encouraged changes in people's lifestyles, especially in Indonesia, which demands that everything be faster and more practical, not least in meeting food needs, so the existence of the internet has now provided opportunities and used as a momentum for business actors to trade their products online. The presence of online media makes it easier for consumers and business actors to access 
Konfrontasi Journal: Culture, Economy and Social Changes, 8 (4) December 2021, 265-272

ISSN: 1410-881X (Print), 2716-2095 (Online)

Maswandi, Jamillah, Widyawati Anggresia Manihuruk: Legal Protection for Consumers on Online Trade of Imported Food Products That Do Not Have a Circulation License in Indonesia DOI: https://doi.org/10.33258/konfrontasi2.v8i4.163

http://www.konfrontasi.net/index.php/konfrontasi2

buying and selling transactions. The online media that are widely used by business actors include Instagram, Facebook, WhatsApp, and Line, because they can make it easier for business actors to reach quite a lot of consumers.

\section{Review of Literature}

Online transactions generally place consumers in a weak position because consumers and business actors do not meet directly so that the potential for consumers to experience losses is higher. One of the actions of business actors that can harm consumers is by trading food products that do not meet safety requirements (Celina Tri Siwi Krisdayanti, Consumer Protection Law, 2009).

The security requirements referred to here are all food, both domestic and foreign (imported) whose purpose is to be traded, must have a distribution permit. Meanwhile, the distribution permit according to Article 1 number 15 of BPOM Regulation No. 30 of 2017 concerning Supervision of the Importation of Drugs and Food into the Indonesian Territory is a form of food registration approval issued by the Head of the Food and Drug Supervisory Agency for circulation in the Indonesian territory. The existence of this distribution permit is indicated by a registration number issued by the Food and Drug Supervisory Agency (BPOM) on the packaging label of the imported food products being traded. The obligation to have a distribution permit for business actors is regulated in Article 91 paragraph (1) of Law Number 18 of 2012 concerning Food which states: "In terms of control of safety, quality, and nutrition, every Processed Food made domestically or imported for trading in retail packaging, food business actors are required to have a distribution permit".

For business actors, trade in imported food products that do not have a distribution permit has clearly violated consumer rights, one of which is legal protection for consumers themselves in the use of food products because protection is a form of consumer rights guaranteed in Article 4 letter (a). Law Number 8 of 1999 concerning Consumer Protection, namely the right to comfort and safety in consuming goods and services. This allows consumers to obtain goods that are guaranteed safety. Consumers will enjoy this protection if the goods in circulation and consumer consumption do not comply with applicable regulations or should apply (Yusuf Shofie, Pelaku Usaha, Konsumen dan Tindak Pidana Korporasi, 2002). In buying and selling transactions, business actors often do not pay attention to the condition of the products being sold, even though such conditions are very important or main things in transactions, where if the actions of such business actors are not considered, it will be very detrimental to consumers.

The absence of legal protection for consumers on trade in food imported products that do not have a distribution permit has proven the weakness of the government's supervision of business actors who freely trade food without a distribution permit, thereby simultaneously making the provisions made relating to Consumer protection and the role of BPOM do not seem to function, even though the completeness of state apparatus such as the police can take legal action for business actors who do not have a distribution permit, there is no need to doubt it.

Apart from that, the level of consumer awareness of their rights is still low. The position of consumers as a weak party is also recognized internationally as reflected in the United Nations Assembly Resolution, No. A/RES/39/248 of 1985 concerning Guidelines for Consumer Protection, which requires that consumers have certain basic rights, namely the right to obtain clear, correct and honest information, the right to obtain security and 
safety, the right to vote, the right to be heard, the right to obtain compensation, the right to obtain basic human needs, the right to a good environment, and the right to obtain basic education (Susanti Adi Nugroho, Consumer Dispute Resolution Process Judging from the Procedural Law and Obstacles in Its Implementation , 2005).

Without maximum supervision from the state against business actors trading imported food products, this is a gap for business actors who trade imported food products who do not have a distribution permit to do as they please, especially since the Indonesian government has not regulated the trade of imported food products online. For this reason, consumer protection is needed to avoid imported food products that are traded without having a distribution permit from the Center for Drug and Food Control that are traded online.

\section{Results and Discussion}

\subsection{The Importance of Legal Protection for Consumers for Online Food Product Trading}

In Indonesia in 1999, a statutory regulation was born, namely Law Number 8 of 1999 concerning Consumer Protection. The Consumer Protection Law has been in effect since April 20, 2000, this Law was born with the aim of providing legal certainty to consumers so that they really get a protection. This Law also stipulates the responsibilities of business actors, which of course is to provide legal certainty and protect the rights of consumers.

Although this law is a Consumer Protection Law, it does not mean that the interests of business actors are not taken into account, it's just that the protection for consumers based on the above definition is based on the position of consumers who are much weaker than business actors (Ahmad Miru and Sutarman Yodo, Consumer Protection Law, 2010). Considering that consumer protection questions the legal protection provided to consumers to obtain goods and services so as not to allow losses due to their users, it can be said that the consumer protection law is a law that regulates the provision of protection to consumers in order to meet their needs as consumers. Therefore, the consumer protection law regulates the rights and obligations of business actors and how to defend these rights and obligations.

Janus Sidabalok stated that there are 4 (four) reasons why consumers need to be protected, which are as follows:

1. Protecting consumers is tantamount to protecting the entire nation as mandated by the national development goals according to the 1945 Constitution.

2. Protecting consumers is necessary to prevent consumers from the negative impact of using technology.

3. Protecting consumers is necessary to produce human beings who are physically and mentally healthy as development actors, which also means maintaining the continuity of national development.

4. Protecting consumers to ensure sources of development funds are sourced from the consumer community (Janus Sidabalok, Consumer Protection Law in Indonesia, 2006).

Food is one of the factors that directly affect the condition of human health. Food that is safe, quality and nutritious is needed by the body to support activities. On the other hand, food that does not meet safety, quality and nutritional standards will endanger the health of the body. Therefore, the selection of food before consumption is very important in order to avoid food products that do not meet standards and can endanger health. So that realizing consumer protection is to realize the relationship of various dimensions which are 
interconnected and interdependent between consumers, business actors and the government (tripartite relationship).

Business people claim that it is easier to market food products through an online shop or online shop which can be said is one of the media that makes it very easy for people to buy and sell goods without meeting face to face because everything is done online or only through the internet. The various forms of Online Shop or online stores that can be recognized in the current trading system, namely:

\section{Online Shop Classifieds (Classified Ad List)}

The first online shop in Indonesia to use simple forms of online business such as classified ads or commonly referred to as classifieds. This form of business does not involve the e-commerce service provider directly. So transactions only involve sellers and buyers, so transactions that occur between sellers and buyers are beyond the knowledge of the e-commerce service provider. Examples of online shops that use classifieds business are Kaskus and OLX.

\section{Marketplace Customer to Customer (C2C)}

In contrast to the classifieds system, an online shop with a $\mathrm{C} 2 \mathrm{C}$ business model, service providers provide facilities, for example as a method of promoting their merchandise. In addition, this service provider also provides services from payment methods from direct transactions. In this online shop business, there is an escrow or legal agreement, where an item (generally in the form of money, but can also be any other object) is kept by a third party (called an escrow agent) while waiting for the contents of the contract to be fulfilled. Escrow is better known as a joint account. After the agreement between the seller and the buyer. Then the buyer will transfer the money to escrow. Then the seller will send the goods ordered by the buyer. Meanwhile, service providers will benefit from a premium advertising system and commissions from escrow services. Examples of successful online shops with this buying and selling method are Tokopedia and Bukalapak.

3. Marketplace Business to Consumer (B2C)

This online shop type has its own website where it sells its products directly to consumers. This business model is profitable by selling its products. For example Lazada, Bhineka, BerryBenka, Blina and Tiket.

4. Social Media Based

Unlike other online shops that have their own website address, this business model uses social media as a means of selling. Get started with Facebook, Instagram, Line/WhatsApp and more.

For business people, they usually prefer to use Instagram because the first target is the person closest to them, it can also be through friends who initially said by word of mouth while showing an Instagram account, this communication is very effective for sellers, with Instagram media it is easier for sellers to show photos. or catalog of goods sold. In this case, the process indirectly forms a series of marketing communications.

Likewise, consumers who are interested in this online media business no longer pay attention to whether the business actor of the food product has a distribution permit or not and does not pay attention to the process of making the product, so they buy and use it without paying attention to the quality of the food product. This unsupervised food used by consumers will certainly pose a risk to their health, so legal protection is needed for the rights of these consumers.

Every business actor is responsible for the products they produce or trade. The responsibility of this business actor is due to the loss suffered by the consumer, perhaps due to inaccuracies in production, not as promised, or the fault of the business actor. So 
that legal protection for consumers is something that is very important so that consumers do not experience large losses, apart from material losses as well as losses to health.

\subsection{Circulation of Imported Food Products That Do Not Have a Permit to Trade Online}

One of the institutions authorized to supervise business actors who trade food products in the form of healthy, safe and quality food in Indonesia is the Center for Drug and Food Control (BPOM) which also has various internal regulations relating to food products, where in the existing regulations it is stated that the community has the right to food products that are healthy, safe, and of good quality. However, in reality, as is known, the circulation of imported food products that do not have a distribution permit is still widely circulated in the community.

There are still many imported food products that do not have distribution permits in the community, proving that BPOM's supervision is still less stringent, this is due to a lack of public awareness of their rights. Therefore, BPOM supervision with a strong legal basis is very important to conduct an assessment during the registration of these imported food products.

The reality is that there are still many imported food products that do not have a distribution permit containing ingredients that endanger public health in various parts of Indonesia, so the aspect of consumer protection to obtain comfort, security, and safety in consuming goods and/or services is still not fulfilled and does not meet the wishes of the people. There are several factors that still find many imported food products that do not have a distribution permit that are traded online due to several things, namely:

a. People prefer imported food products . The number of imported food products circulating in online media makes it easier for people to get them more practically.

b. Lack of understanding of the procedures and procedures for the registration of imported food products, whereas before the product is traded, it must be registered with relevant agencies such as BPOM and the Ministry of Trade of the Republic of Indonesia.

c. Fear of being subject to import duties and taxes so as to increase production costs resulting in high product prices.

d. Want everything instantaneously without going through a long process to get cheap goods and quickly get the desired profit. In monitoring imported food trade through online media, it is still very difficult to supervise as a whole, however, the act of supervising the inspection of imported production activities, distribution, use and promotion of imported food products includes the authority to:

1. Entering every place suspected of being used in the activities of production, import, distribution, storage, transportation, and delivery of food products to inspect, examine, and take samples of everything used in the activities of production, import, distribution, storage, transportation and delivery of products imported food.

2. Checking documents or other records containing information regarding the activities of production, import, distribution, storage, transportation, and delivery of imported food products.

3. Ordered to show business licenses and other documents. Because the supervision of imported food sold through online media is still difficult to monitor as a whole.

4. Appeal to the public if they find imported food products that do not have a distribution permit and are considered to contain hazardous materials in them, 
they are expected to report to BPOM, so that follow-up actions can be taken as a preventive measure.

Supervision by BPOM on imported food is supervision to protect the public and ensure that food during production, handling, storage, processing and distribution is safe, healthy, fit for human consumption, meets quality and safety requirements in accordance with established regulations. Many imported foods enter Indonesia sometimes without clear information on the product packaging. On the packaging of imported food products usually use a foreign language that is not accompanied by communicative Indonesian, so that consumers do not know the content and composition of the food product. If it is related to the consumer's right to safety, then every product that contains a risk to consumer safety must be accompanied by information in the form of clear usage instructions.

Often the data information contained in the packaging of imported food products is manipulated by hiding the use of hazardous chemicals contained in food, including formalin, borax, and rhodamine-b which are usually used to preserve corpses and as food coloring. If the packaging in the product contains incorrect information, then the act meets the criteria for a crime commonly called fraudulent misrepresentation. This form of crime is characterized by the use of false statements and misleading statements.

Indeed, BPOM must be able to protect consumers from imported food containing hazardous chemicals. Considering that public knowledge is still not sufficient to be able to choose and use imported products correctly, correctly and safely. Advertisements and promotions through online media are also very intense so that it encourages consumers to consume excessively and often irrationally. Indonesia must have an effective and efficient Drug and Food Control System (SisPOM) capable of detecting, preventing and supervising imported products to protect the security, safety and health of consumers. Supervision of drug and food products in Indonesia is carried out by the Food and Drug Supervisory Agency (Badan POM). The reality is that without the participation of the community, both groups and individuals and nongovernmental organizations, BPOM cannot carry out its supervisory duties optimally.

\subsection{Legal Sanctions for Business Actors Who Do not have a Distribution Permit for Online Trading of Imported Food Products}

The existence of sanctions for business actors in online trading of imported food products indirectly gives consumers a strong position to sue business actors who violate this provision. To suppress or threaten business actors who are judged to be in default on food product sales services that do not have a distribution permit from BPOM. In the supervision carried out by BPOM against business actors who violate, the first steps taken as a follow-up are as follows:

a. Products found are destroyed by BPOM.

b. Order to return to dealer as product security.

c. For business actors who circulate, make a statement not to resell products that do not have a distribution permit as well asthen build.

d. Business actors who commit repeated violations and distribute products in large quantities (deliberately) will be subject to legal proceedings (pro-justicia).

Meanwhile, according to Law Number 8 of 1999 concerning Consumer Protection, it divides three aspects, namely criminal sanctions, civil sanctions, and administrative sanctions for violations committed by business actors who trade food products that do not have distribution permits. 
a. Civil Sanctions.

In Law Number 8 of 1999 concerning Consumer Protection there are several articles that describe the product responsibility system in consumer protection law in Indonesia, namely the provisions of Article 19 of Law no. 8 of 1999 concerning Consumer Protection defines producer responsibilities. Article 28 of the Consumer Protection Law states that proving whether or not there is an element of error in a claim for compensation is the burden and responsibility of the business actor. This means that the best evidence system applies, both in criminal and civil cases.

b. Criminal sanctions.

Criminal sanctions in the Consumer Protection Law are regulated in Articles 61, 62, 63 of the UUPK and Law no. 7 of 1996 Articles 55, 56, 57, 58, 59. BPOM through the field of investigation if it finds a business actor who sells food products that do not have a distribution permit in large quantities and is deliberately traded, then BPOM will proceed legally (projusticia). ). In the prosecution carried out by BPOM Medan itself more often uses the provisions of Law Number 7 of 1996 concerning Food, because the provisions on food itself are more specifically regulated by Law Number 7 of 1996 concerning Food. Law Number 8 of 1999 concerning Consumer Protection can also be used in the case of prosecuting BPOM because business actors violate the provisions of the relationship between the rights and obligations of business actors and consumers. So the use of criminal provisions can be seen from which provisions meet the violations committed by the business actors themselves.

c. Administrative Sanctions

Administrative sanctions are not aimed at consumers in general, but rather to entrepreneurs, both producers and distributors of their products. Administrative sanctions are related to the permits granted. government to the entrepreneur/distributor. If there is a violation, these permits can be revoked unilaterally by the government. Administrative sanctions only aim to stop the production process of the producer/distributor. The rights of consumers who are harmed can be prosecuted with civil and/or criminal legal assistance.

The legal sanction for distributing food that does not have a distribution permit is contained in Article 142 Jo. Article 91 paragraph (1) of the Republic of Indonesia Law no. 18 of 2012 concerning Food which reads: Food Business Actor who intentionally does not have a distribution permit for any Processed Food made domestically or imported to be traded in packaging as referred to in Article 91 paragraph (1) shall be punished with imprisonment for a maximum of 2 (two) years or a maximum fine of Rp. 4,000,000,000.00 (four billion rupiah) and Article 62 paragraph (1) of the Republic of Indonesia Law no. 8 of 1999 concerning Consumer Protection, for distributing food products that do not have a distribution permit, and the sanctions given in accordance with Article 62 paragraph (1) of Law No. 8 of 1999 concerning Consumer Protection with a maximum imprisonment of 5 (five) years or a maximum fine of Rp. 2,000,000,000.00 (two billion rupiah). 


\section{Conclusion}

Legal protection for consumers related to the sale and purchase of imported food products is very important to ensure the achievement of quality, health and comfort in people's lives. The existence of Law no. 8 of 1999 concerning Consumer Protection has not made an adequate contribution, which is due to the absence of regulations relating to supervision of business actors who run their business through online trading of imported food products which are widespread in the community who are free to run their business without a distribution permit. from the Food and Drug Administration (BPOM) in Indonesia.

There are still many imported food products that do not have a distribution permit in the community, this is evidence that BPOM as an institution authorized to supervise business actors has not worked well, so that the public as consumers feel that they do not get protection, both legal protection as stipulated in the Act. , as well as the protection of the authorized institution, namely BPOM itself.

Given the absence of legal protection in the form of supervision as regulated in Law no. 8 of 1999 concerning Consumer Protection, in the community there are many business actors who do not have a distribution permit for trade in imported food products through online media, so that many people buy food products that are of poor quality, damage health and are not safe for consumption even though sanctions are imposed on them. for business actors without a distribution permit from BPOM it can be done at once both criminally, civilly and administratively.

\section{References}

Celina Tri Siwi Krisdayanti, Hukum Perlindungan Konsumen, Jakarta: Sinar Grafika, 2009

Yusuf Shofie, Pelaku Usaha, Konsumen dan Tindak Pidana Korporasi, Jakarta: Ghalia Indonesia, 2002

Susanti Adi Nugroho, Proses Penyelesaian Sengketa Konsumen Ditinjau dari Hukum Acara Serta Kendala Implementasinya, Jakarta: Prenadamedia Group, 2005,

Ahmad Miru dan Sutarman Yodo, Hukum Perlindungan Konsumen, Jakarta: PT Raja Grafindo Persada, 2010.

Janus Sidabalok, Hukum Perlindungan Konsumen di Indonesia, Bandung: PT.Citra Aditya Bakti, 2006

Undang-Undang Nomor 8 Tahun 1999 Tentang Perlindungan Konsumen.

Undang-Undang Nomor 18 Tahun 2012 Tentang Pangan. 